\title{
Morphological and functional changes of microglia cultured under different oxygen concentrations and the analysis of related mechanisms
}

\author{
XING WU ${ }^{1}$, TENGBO YU ${ }^{2}$, HONGYAN XU ${ }^{3}$, XIUMING SUN ${ }^{1}$, DEWEI KOU ${ }^{1}$ and LIPING LI ${ }^{4}$ \\ Departments of ${ }^{1}$ Pain Clinic and ${ }^{2}$ Bone Surgery, The Affiliated Hospital of Qingdao University; \\ ${ }^{3}$ Zone One, Qingdao The First Sanatorium of PLA Navy; ${ }^{4}$ Department of Bone Surgery, \\ Qingdao Central Hospital, Qingdao, Shandong 266000, P.R. China
}

Received July 14, 2017; Accepted November 2, 2017

DOI: $10.3892 /$ etm.2017.5596

\begin{abstract}
This study investigated the effects of different concentrations of oxygen exposure on the morphology and function of N9 microglia and analyzed its mechanisms. N9 microglia were cultured under the condition of high $\left(95 \% \mathrm{O}_{2}\right.$ and $\left.5 \% \mathrm{CO}_{2}\right)$, normal $\left(95 \%\right.$ air and $\left.5 \% \mathrm{CO}_{2}\right)$ and low oxygen $\left(95 \% \mathrm{CO}_{2}\right.$ and $5 \% \mathrm{O}_{2}$ ) concentrations. The cell morphologies were observed under inverted phase contrast microscope after $24 \mathrm{~h}$. Flow cytometry was applied to detect cell survival and apoptotic rate. The mRNA and protein expression levels of interleukin-1 $\beta$ (IL-1 $\beta$ ) and tumor necrosis factor- $\alpha(\mathrm{TNF}-\alpha)$ were detected by reverse transcription-polymerase chain reaction (RT-PCR) and western blot analysis, respectively. The results showed that, N9 microglial apoptotic rates in hyperoxia and hypoxia conditions were significantly higher than those in the normal group $(\mathrm{P}<0.05)$ and the apoptosis rate in the hypoxia group was higher than that in the hyperoxia group $(\mathrm{P}<0.05)$. The mRNA and protein expression levels of IL-1 $\beta$ and TNF- $\alpha$ in the hyperoxia and hypoxia groups were significantly higher than those in the normal group $(\mathrm{P}<0.05)$ and the mRNA and protein expression levels in hypoxia group were higher than those in the hyperoxia group $(\mathrm{P}<0.05)$. Therefore, $\mathrm{N} 9$ microglia cultured under hyperoxia and hypoxia conditions can be activated, enhancing pro-inflammatory response and inducing cell apoptosis. The mechanism may be that the secretion of neurotoxic factors IL-1 $\beta$ and TNF- $\alpha$ is involved in these responses.
\end{abstract}

\section{Introduction}

Most of the cells in the central nervous system are glial cells. These cells are widely distributed (1). Microglia are innate

Correspondence to: Dr Tengbo Yu, Department of Bone Surgery, The Affiliated Hospital of Qingdao University, 16 Jiangsu Road, South District, Qingdao, Shandong 266000, P.R. China

E-mail: tengbo_yu@163.com

Key words: microglia, oxygen concentration, IL-1 $\beta$, TNF- $\alpha$ immune cells of the central nervous system and account for approximately $20 \%$ of the glial cells (2).

Microglia constitute the main immune defense line in the mature central nervous system and are closely related to the pathological and physiological changing processes of most central nervous system diseases $(3,4)$. Under the conditions of disease stimulation, the activated microglia exert immune phagocytic effects and eliminate necrotic cells and infectious substances in the central nervous system (5). Nevertheless, excessive activation of microglia produces neurotoxicity factors such as interleukin-1 $\beta$ (IL-1 $\beta$ ) and tumor necrosis factor- $\alpha$ (TNF- $\alpha$ ), which mediate excessive immune response, causing additional damage to the central nervous system $(4,6)$.

The morphological and functional changes of microglia activated under different stimulations are not completely clear. Thus, the aim of this study was to investigate the morphological and functional changes of N9 microglia under the culture conditions of different oxygen concentrations and to explore the underlying mechanisms.

\section{Materials and methods}

\section{Materials}

Cell lines. Mouse N9 microglia cell lines were purchased from the Cell Culture Center of Peking Union Medical College (Beijing, China).

Main reagents. Dulbecco's modified Eagle's medium (DMEM) and fetal bovine serum (FBS) were purchased from HyClone (Los Angeles, CA, USA). The goat serum was obtained from Sigma-Aldrich (St. Louis, MO, USA). Penicillin and streptomycin were obtained from Nanjing KeyGen Biotech (Nanjing, China). Trypsin, Annexin V Cell Apoptosis Detection kit, protein lysis buffer, the anti-mouse/rat IL-1 $\beta$, anti-rabbit/ rat TNF- $\alpha$ and anti-sheep/rat $\beta$-actin antibodies, the TRIzol reagent, the reverse transcription and cDNA amplification kits were all purchased from Abcam (Cambridge, UK).

Main instruments. The inverted phase contrast microscope was purchased from Olympus (Tokyo, Japan), the cell culture incubator was obtained from Thermo Fisher Scientific 
(Waltham, MA, USA), the super clean bench was obtained from Escolifesciences (Shanghai, China), the flow cytometer was purchased from BD Biosciences (Franklin Lakes, NJ, USA), the PCR Amplifier was purchased from Bio-Rad (Berkeley, CA, USA) and the micropipette was obtained from Eppendorf (Hamburg, German).

\section{Methods}

Culturing and grouping of N9 microglia. N9 microglia in a frozen pipe was obtained from liquid nitrogen. The tube was waved in a water bath of $37^{\circ} \mathrm{C}$ for $1-2 \mathrm{~min}$. After being thawed, the cells were transferred to a centrifuge tube and the DMEM was added to the tube. The precipitated cells were collected after centrifugation for $5 \mathrm{~min}$ at 9,010 $\mathrm{xg}$ to remove the cell precipitate. Complete DMEM was added to blow and resuspend the cells. The cells were transferred to a $75 \mathrm{ml}$ culture flask. The DMEM containing FBS was added. The cells were incubated at $37^{\circ} \mathrm{C}$ with $5 \% \mathrm{CO}_{2}$ for 2 to 3 days. Cells adhering to the bottom of the flask were digested using trypsin and the cell passage was performed at 1:4, followed by routine subculture in an incubator. The same generation of cultured cells was then collected for the experiment. The cells were identified to determine whether they met the characteristics of N9 microglia. The cells were resuspended with DMEM and the density was adjusted prior to placing the cells in 6-well plates. The cells were divided into the high oxygen concentration (H group), normal ( $\mathrm{N}$ group) and low oxygen concentration ( $\mathrm{L}$ group) groups. The culture parameters of the $\mathrm{H}$ group were: $37^{\circ} \mathrm{C}, 95 \% \mathrm{O}_{2}$ and $5 \% \mathrm{CO}_{2}$. The culture parameters of the $\mathrm{N}$ group were: $37^{\circ} \mathrm{C}, 95 \%$ air and $5 \% \mathrm{CO}_{2}$. Culture parameters of the $\mathrm{L}$ group were: $37^{\circ} \mathrm{C}, 95 \% \mathrm{CO}_{2}$ and $5 \% \mathrm{O}_{2}$. High glucose DMEM containing $10 \%$ FBS was added to all of the groups and cultured under the predetermined conditions. The morphology of N9 microglia was observed under inverted phase contrast microscope (Olympus, Tokyo, Japan) after the cells were incubated for $24 \mathrm{~h}$.

Detection of N9 microglia apoptosis. Flow cytometry was used to analyze adherent cells that were collected after digestion with trypsin. After being washed twice with phosphate-buffered saline (PBS), the cells were centrifuged at $9,010 \mathrm{x} g$ for $5 \mathrm{~min}$. Supernatants were abandoned and the cells were resuspended in PBS. The apoptosis reagent of Annexin V was added and the cells were incubated for $15 \mathrm{~min}$ in the dark at room temperature. Then the apoptotic rates were detected by using a flow cytometer.

$m R N A$ expression levels of $I L-1 \beta$ and TNF- $\alpha$. mRNA expression levels of IL-1 $\beta$ and TNF- $\alpha$ in N9 microglia cultured under different oxygen concentrations were detected by reverse transcription-polymerase chain reaction (RT-PCR). Cells were collected after trypsinization and cell lysis was conducted at low temperature. The total RNA was extracted, cDNA was synthesized by reverse transcription, followed by a PCR amplification experiment. $\beta$-actin was set as an inner reference. The primer sequences used were: IL-1 $\beta$ forward, 5'-ATCTCGCAGCAGCACATC-3' and reverse, 5'-CCAGCAGGTTATCATCATCATC-3'. TNF- $\alpha$ forward, 5'-CGCTACGACCGCCAGATTG-3' and reverse, 5'-ACACCGTTCACCAGCAAGTC-3'. $\beta$-actin forward,
5'-CATGGGGTGTGAACCATGAGA-3' and reverse 5'-GTC TTCTGGGTGGCAGTGAT-3'. The amplification conditions were as follows: Predegeneration at $94^{\circ} \mathrm{C}$ for $2 \mathrm{~min}, 94^{\circ} \mathrm{C}$ for $30 \mathrm{sec}, 6^{\circ} \mathrm{C}$ for $30 \mathrm{sec}$ and $72^{\circ} \mathrm{C}$ for $60 \mathrm{sec}$, a total of $28 \mathrm{cycles}$; and extension at $72^{\circ} \mathrm{C}$ for $5 \mathrm{~min}$. The amplified products were separated in a $20 \mathrm{~g} / \mathrm{l}$ agarose gel electrophoresis. A gel imaging analysis system (Bio-Rad) was applied to detect the gray scale values of band. The gray value ratio of the target gene (IL-1 $\beta$ and $\mathrm{TNF}-\alpha$ ) to the reference gene $\beta$-actin was regarded as a relative expression of the target gene.

Protein expression levels of $I L-1 \beta$ and TNF- $\alpha$. The protein expression levels of IL-1 $\beta$ and TNF- $\alpha$ in N9 microglia under different oxygen concentrations were detected by western blot analysis. The cells were scraped from the flask. The lysis buffer was added to extract total protein. The protein concentration was measured using the BCA Protein Quantitative kit. SDS polyacrylamide gel (10\%) was prepared and subjected to electrophoresis after $20 \mu \mathrm{g}$ proteins were loaded. The proteins were transferred onto a membrane and then blocked by $5 \%$ skim milk at room temperature for $2 \mathrm{~h}$. The anti-mouse/rat IL-1 $\beta$ (dilution, 1:2,000; cat. no. ab33738) and TNF- $\alpha$ (dilution, 1:5,000; cat. no. 11564) (both from Abcam) primary monoclonal antibodies were added and the protein was incubate overnight at $4^{\circ} \mathrm{C}$. The membranes were washed in TBST buffer and then incubated with anti-sheep/rat $\beta$-actin monoclonal (dilution, 1:5,000; cat. no. ab50591; Abcam). After being developed, band images were collected and analyzed.

Statistical analysis. Data were collected and analyzed using SPSS 17.0 software (SPSS, Inc., Chicago, IL, USA). Measuring data were expressed as mean \pm standard deviation (SD). The data were compared by one-way ANOVA. he LSD t-test was used for pairwise comparisons between group means. $\mathrm{P}<0.05$ was considered to indicate a statistically significant difference.

\section{Results}

Effects of different oxygen concentrations on morphology of N9 microglia. Under normal conditions, the cells in the $\mathrm{N}$ group were resting and the cells were spindle-shaped. Cell processes were thin and long. Under the conditions of high and low oxygen concentration, the N9 microglia was activated, cells in the $\mathrm{H}$ and $\mathrm{L}$ groups were round and the cell processes disappeared (Fig. 1).

Effects of different oxygen concentrations on N9 microglia apoptosis. After cells were cultured at different oxygen concentrations for $24 \mathrm{~h}$, the apoptotic rates of N9 microglia in the $\mathrm{L}$ and $\mathrm{H}$ group were significantly higher than those in $\mathrm{N}$ group $(\mathrm{P}<0.05)$ and the apoptotic rate of $\mathrm{L}$ group was higher than that in the $\mathrm{H}$ group $(\mathrm{P}<0.05)$. The results showed statistical differences (Fig. 2).

Effects of different oxygen concentrations on the $m R N A$ expression levels of $I L-1 \beta$ and $T N F-\alpha$. After cells were cultured at different oxygen concentrations for $24 \mathrm{~h}$, the mRNA expression levels of IL-1 $\beta$ and TNF- $\alpha$ of N9 microglia in the $\mathrm{L}$ and $\mathrm{H}$ groups were significantly higher than those in the $\mathrm{N}$ group $(\mathrm{P}<0.05)$ and the mRNA expression levels of 

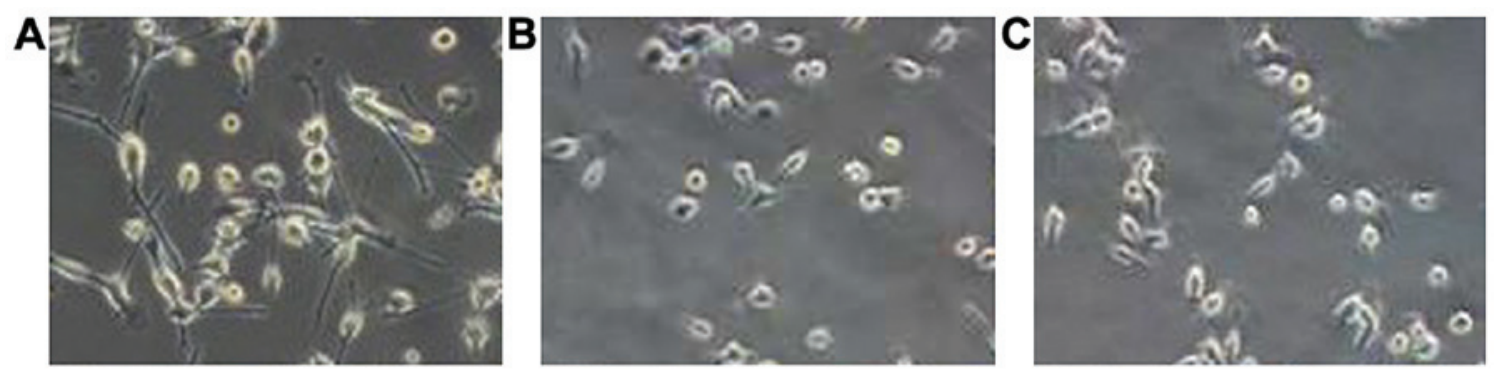

Figure 1. Effects of different oxygen concentrations on morphology of N9 microglia. (A) Normal group: The cells are spindle-shaped, with thin and long cell processes. (B) High and (C) low oxygen concentration group: The cells are round and the cell processes disappeared.

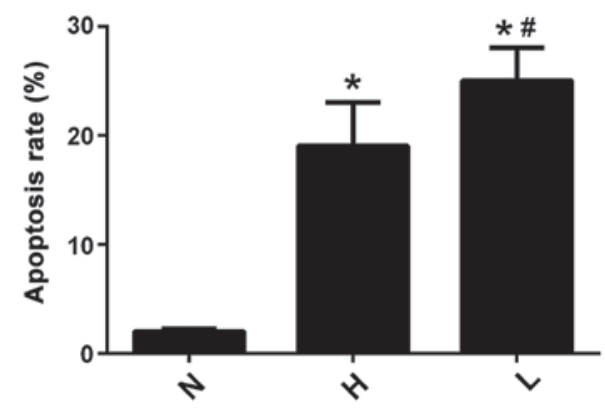

Figure 2. Cell apoptosis rates of N9 microglia cultured under different oxygen concentrations. The results of flow cytometry show that compared with the $\mathrm{N}$ group, the apoptotic rates of $\mathrm{N} 9$ microglia in the $\mathrm{L}$ and $\mathrm{H}$ groups are significantly increased. The apoptotic rate of the $\mathrm{L}$ group is higher than that in the $\mathrm{H}$ group $(\mathrm{P}<0.05)$. Compared with $\mathrm{N}$ group, ${ }^{*} \mathrm{P}<0.05$; compared with $\mathrm{H}$ group, ${ }^{, \mathrm{P}}<0.05$.

A

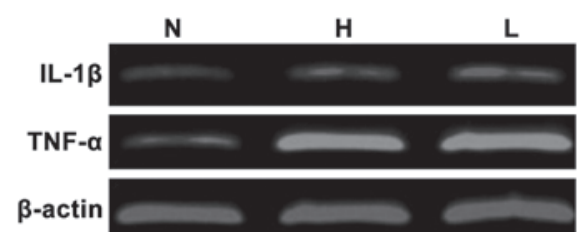

B

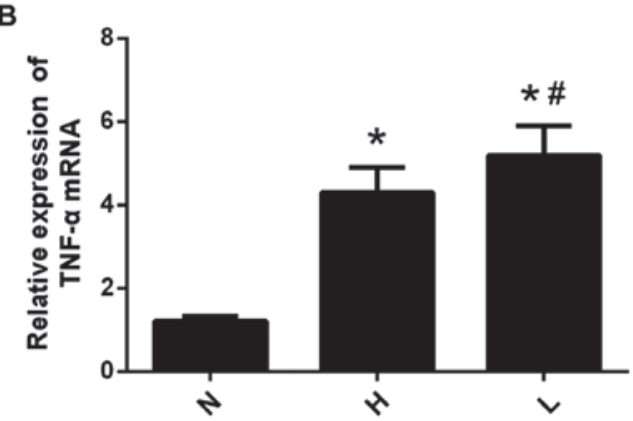

Figure 3. (A and B) Effects of different oxygen concentrations on the mRNA expression levels of IL-1 $\beta$ and TNF- $\alpha$. Cells were incubated at different oxygen concentrations for $24 \mathrm{~h}$, the RT-PCR results show that the mRNA expression levels of IL-1 $\beta$ and TNF- $\alpha$ of N9 microglia in the L and $\mathrm{H}$ groups are significantly higher than those in the $\mathrm{N}$ group $(\mathrm{P}<0.05)$ and the mRNA expression levels of IL- $1 \beta$ and TNF- $\alpha$ of N9 microglia in the L group are higher than those in the $\mathrm{H}$ group $(\mathrm{P}<0.05)$. The results show statistical differences. Compared with $\mathrm{N}$ group, ${ }^{*} \mathrm{P}<0.05$; compared with $\mathrm{H}$ group, ${ }^{*} \mathrm{P}<0.05$. IL-1 $\beta$, interleukin-1 $\beta$; TNF- $\alpha$, tumor necrosis factor- $\alpha$.

IL-1 $\beta$ and TNF- $\alpha$ of N9 microglia in L group were higher than those in $\mathrm{H}$ group $(\mathrm{P}<0.05)$. The results showed statistical differences (Fig. 3).
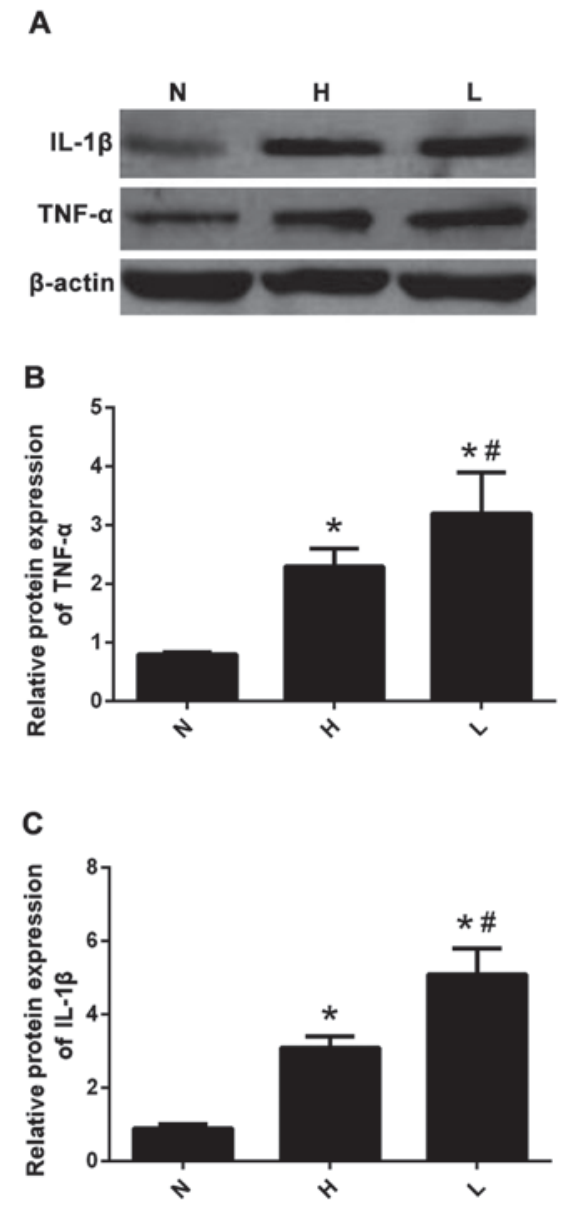

Figure 4. (A-C) Effects of different oxygen concentrations on the protein expression of IL- $1 \beta$ and TNF- $\alpha$. The RT-PCR results show that the protein expression levels of IL-1 $\beta$ and TNF- $\alpha$ of $\mathrm{N} 9$ microglia in $\mathrm{L}$ and $\mathrm{H}$ groups are significantly higher than those in $\mathrm{N}$ group $(\mathrm{P}<0.05)$ and the protein expression levels of IL-1 $\beta$ and TNF- $\alpha$ of N9 microglia in L group are higher than those in $\mathrm{H}$ group $(\mathrm{P}<0.05)$. The results show statistical differences. Compared with $\mathrm{N}$ group, ${ }^{\mathrm{P}} \mathrm{P}<0.05$; compared with $\mathrm{H}$ group, ${ }^{\prime} \mathrm{P}<0.05$. IL-1 $\beta$, interleukin- $1 \beta$; TNF- $\alpha$, tumor necrosis factor- $\alpha$.

Effects of different oxygen concentrations on the protein expression levels of $I L-1 \beta$ and TNF- $\alpha$. After cells were cultured at different oxygen concentrations for $24 \mathrm{~h}$, the protein expression levels of IL-1 $\beta$ and TNF- $\alpha$ of N9 microglia in the L and $\mathrm{H}$ groups were significantly higher than those in the $\mathrm{N}$ group $(\mathrm{P}<0.05)$ and the protein expression levels of IL-1 $\beta$ and TNF- $\alpha$ of N9 microglia in L group were higher than those in $\mathrm{H}$ group $(\mathrm{P}<0.05)$. The results showed statistical differences (Fig. 4). 


\section{Discussion}

Microglia are mainly from bone marrow precursor and are innate immune cells of the central nervous system (7). Under normal conditions, the microglia are at resting state, controlling and maintaining the normal physiological environment of the central nervous system $(8,9)$. When pathological changes such as stroke, trauma, infection, tumor and central nervous system degenerative diseases appear in the central nervous system, the microglia are activated and a large number of neurotoxic factors such as IL-1 $\beta$ and TNF- $\alpha$ are released, which triggers a series of inflammatory reactions and leads to the activation and migration of microglia around the area of the lesion (10-13). A serious immune response to the body occurs when the microglia activation process is out of control, which aggravates central nervous system injury $(14,15)$. At present, there are relatively few studies regarding the microglia. The morphological and functional changes and mechanisms of activated microglia under different pathological conditions are not completely clear. Therefore, the N9 microglia were cultured under the environment of different oxygen concentrationa and the effects of different oxygen concentrations on the morphology and function of microglia were observed. The results showed that hyperoxia $\left(95 \% \mathrm{O}_{2}\right.$ and $\left.5 \% \mathrm{CO}_{2}\right)$ and hypoxia $\left(95 \% \mathrm{CO}_{2}\right.$ and $5 \% \mathrm{O}_{2}$ ) had significant cytotoxicity to $\mathrm{N} 9$ microglia, which leads to morphological changes and disappearance of cell process, cell activation and increased cell apoptosis.

IL- $1 \beta$ is an inflammatory factor produced by activated microglia. IL-1 $\beta$ can enhance the activities of immune cells leading to the release of the inflammatory medium, which causes self-tissue damage while enhancing body immunity and the degree of injury is positively correlated with the concentration of IL-1 $\beta$ (16-18). TNF- $\alpha$ is a naturally proinflammatory cytokine and has a wide range of biological effects, which is involved in the process of cellular immune response (19-21). TNF- $\alpha$ is mainly produced by microglia in the central nervous system. TNF- $\alpha$ induces neutrophil chemotaxis and induces the body to synthesize the IL-6, IL- 8 and other inflammatory factors, which promotes inflammatory response, induces cell apoptosis and increases tissue damage (22). In the present study, we found that the mRNA and protein expression levels of IL-1 $\beta$ and TNF- $\alpha$ in N9 microglia were increased after the cells were cultured in hyperoxic and hypoxic environments for $24 \mathrm{~h}$, which indicated that peroxidation and hypoxia stimulation can induce the secretion of pro-inflammatory cytokines such as IL-1 $\beta$ and TNF- $\alpha$ in microglia and induce the inflammatory response and may be involved in the process of cell apoptosis. When pathological changes occur in the central nervous system, the resting microglia was activated, and secreted multiple neurotoxicity factors such as TNF- $\alpha$, IL-1 $\beta$ and NO for a long-term, which exerted significant toxic effects to peripheral nerve cells $(13,23)$. Therefore, the activation of microglia may have an important effect on the occurrence and outcome of the central nervous system.

In conclusion, the environmental stimulus of hyperoxia and hypoxia can activate $\mathrm{N} 9$ microglia in vitro, resulting in the increased expression of IL-1 $\beta$ and TNF- $\alpha$ and then inducing cell apoptosis. Therefore, the regulation of IL- $1 \beta$ and TNF- $\alpha$ expression may be a key factor to reduce the damage of the central nervous system caused by peroxidation and hypoxia. The specific molecular and signal pathways remain to be further explored.

\section{References}

1. Borovkova M, Serebriakova M, Fedorov V, Sedykh E, Vaks V, Lichutin A, Salnikova A and Khodzitsky M: Investigation of terahertz radiation influence on rat glial cells. Biomed Opt Express 8: 273-280, 2016

2. Yu AC, Neil SE and Quandt JA: High yield primary microglial cultures using granulocyte macrophage-colony stimulating factor from embryonic murine cerebral cortical tissue. J Neuroimmunol 307: 53-62, 2017.

3. Van Loon NM and Zelcer N: Idolizing the clearance of Amyloid- $\beta$ by microglia. Ann Transl Med 4: 536, 2016

4. Ding F, Li Y, Hou X, Zhang R, Hu S and Wang Y: Oxymatrine inhibits microglia activation via HSP60-TLR4 signaling. Biomed Rep 5: 623-628, 2016.

5. Sarkar S, Döring A, Zemp FJ, Silva C, Lun X, Wang X, Kelly J, Hader W, Hamilton M, Mercier P, et al: Therapeutic activation of macrophages and microglia to suppress brain tumor-initiating cells. Ann Neurosci 20: 154, 2013.

6. Yuan Y, Zha H, Rangarajan P, Ling EA and Wu C: Anti-inflammatory effects of Edaravone and Scutellarin in activated microglia in experimentally induced ischemia injury in rats and in BV-2 microglia. BMC Neurosci 15: 125, 2014.

7. Tarassishin L, Suh HS and Lee SC: Interferon regulatory factor 3 plays an anti-inflammatory role in microglia by activating the PI3K/Akt pathway. J Neuroinflammation 8: 187, 2011.

8. Shin JW, Moon JY, Seong JW, Song SH, Cheong YJ, Kang C and Sohn NW: Effects of tetramethylpyrazine on microglia activation in spinal cord compression injury of mice. Am J Chin Med 41: 1361-1376, 2013.

9. Savic D, Stojiljkovic M, Lavrnja I, Parabucki A, Bjelobaba I, Nedeljkovic N, Herdegen T and Pekovic S: Ribavirin shows immunomodulatory effects on activated microglia. Immunopharmacol Immunotoxicol 36: 433-441, 2014.

10. Zhang H, Li Y, Yu J, Guo M, Meng J, Liu C, Xie Y, Feng L, Xiao B and Ma C: Rho kinase inhibitor fasudil regulates microglia polarization and function. Neuroimmunomodulation 20: 313-322, 2013.

11. Zhang GB, Feng YH, Wang PQ, Song JH, Wang P and Wang SA: A study on the protective role of doxycycline upon dopaminergic neuron of LPS-PD rat model rat. Eur Rev Med Pharmacol Sci 19: 3468-3474, 2015

12. Han B, Lu Y, Zhao H, Wang Y, Li L and Wang T: Electroacupuncture modulated the inflammatory reaction in MCAO rats via inhibiting the TLR4/NF- $\mathrm{BB}$ signaling pathway in microglia. Int J Clin Exp Pathol 8: 11199-11205, 2015.

13. Dong XQ, Du Q, Yu WH, Zhang ZY, Zhu Q, Che ZH, Chen F, Wang $\mathrm{H}$ and Chen J: Anti-inflammatory effects of oxymatrine through inhibition of nuclear factor-kappa B and mitogen-activated protein kinase activation inlipopolysaccharide-induced BV2 microglia cells. Iran J Pharm Res 12: 165-174, 2013.

14. Russo I, Berti G, Plotegher N, Bernardo G, Filograna R, Bubacco L and Greggio E: Leucine-rich repeat kinase 2 positively regulates inflammation and down-regulates NF- $\mathrm{B}$ p50 signaling in cultured microglia cells. J Neuroinflammation 12: $230,2015$.

15. Lee YJ, Park CE, Kim JH, Sohn HJ, Lee J, Jung SY and Shin HJ: Naegleria fowleri lysate induces strong cytopathic effects and pro-inflammatory cytokine release in rat microglial cells. Korean J Parasitol 49: 285-290, 2011.

16. Hanamsagar R, Torres V and Kielian T: Inflammasome activation and IL-1 $\beta /$ IL-18 processing are influenced by distinct pathways in microglia. J Neurochem 119: 736-748, 2011.

17. Tanaka T, Kai S, Matsuyama T, Adachi T, Fukuda K and Hirota K: General anesthetics inhibit LPS-induced IL-1 $\beta$ expression in glial cells. PLoS One 8: e82930, 2013

18. Shi D, Song X, Guo Y, Xu J, Liu Y, Zhang J, Cui CA and Jin DQ: Alismol, a sesquiterpenoid isolated from Vladimiria souliei, suppresses proinflammatory mediators in lipopolysaccharide-stimulated microglia. J Mol Neurosci 62: 106-113, 2017.

19. Zhou R, Yang Z, Tang X, Tan Y, Wu X and Liu F: Propofol protects against focal cerebral ischemia via inhibition of microglia-mediated proinflammatory cytokines in a rat model of experimental stroke. PLoS One 8: e82729, 2013. 
20. Han L, Zhang D, Tao T, Sun X, Liu X, Zhu G, Xu Z, Zhu L, Zhang Y, Liu W, et al: The role of N-glycan modification of TNFR1 in inflammatory microglia activation. Glycoconj J 32: 685-693, 2015.

21. Joo HK, Choi S, Lee YR, Lee EO, Park MS, Lim YP, Park JT and Jeon BH: Ethanol extract of Brassica rapa ssp. pekinensis suppresses tumor necrosis factor- $\alpha$-induced inflammatory response in human umbilical vein endothelial cells. J Med Food 20: 511-518, 2017.

22. Meng L, Xu W, Guo L, Ning W and Zeng X: Paeonol inhibits the proliferation, invasion, and inflammatory reaction induced by TNF- $\alpha$ in vascular smooth muscle cells. Cell Biochem Biophys 73: 495-503, 2015.
23. Camara ML, Corrigan F, Jaehne EJ, Jawahar MC, Anscomb H and Baune BT: Effects of centrally administered etanercept on behavior, microglia, and astrocytes in mice following a peripheral immune challenge. Neuropsychopharmacology 40: 502-512, 2015.

(C) (1) This work is licensed under a Creative Commons cc) Atribution-NonCommercial-NoDerivatives 4.0 International (CC BY-NC-ND 4.0) License. 